\title{
FEATURES OF PHENOTYPIC MANIFESTATIONS, ANAMNESIS, CONNECTIVE TISSUE METABOLISM AMONG CHILDREN ON THE BACKGROUND OF ACUTE BRONCHITIS
}

\author{
Kharkiv National Medical University, Ukraine
}

m.strelkova.doc@gmail.com

High population frequency with the prevalence of connective tissue dysplasia, the unique role of connective tissue in the exercise of various functions of organs and systems of the body significantly affects the clinical course of bronchopulmonary diseases in children. The relationship between the presence of tracheobronchial dyskinesia and other phenotypic signs of "weakness" of connective tissue is noted. The clinical significance of tracheobronchial dyskinesia is that it is one of the causes of bronchial obstruction and chronic cough. Through mechanisms of hyperventilation and local inflammation, bronchial obstruction can lead to the development of emphysema, chronic bronchitis, and pulmonary heart.

The study included 72 inpatients (the $1^{\text {st }}$ group comprised 41 children with acute obstructive bronchitis and the $2^{\text {nd }}$ group had 31 children with acute bronchitis simple).

To assess the status of connective tissue metabolism, the daily excretion of the metabolite of connective tissue - oxyproline in the daily urine sample was determined. The metabolism of glycosaminoglycans was studied by the level of uronic acids in the urine. The level of blood glycosaminoglycans was determined. In establishing the presence of connective tissue dysplasia, the levels of stigmatization (a conditional index that includes the total number of connective tissue dysplasia points with the allocation of low, medium and high levels) were taken into account using the table "Indicators in the severity of connective tissue dysplasia". During the analysis of connective tissue metabolism in the serum of children with acute bronchitis complicated by broncho-obstructive syndrome with connective tissue dysplasia we observed phenotypic changes in the form of a decrease in the total level of the glycosaminoglycans, 2 and 3 fractions of the glycosaminoglycans, as well as an increase in the concentration of chondroitin sulfates of urine. Phenotypic portrait of children of the first group was characterized by dysplastic disorders of the skeleton, skin and its appendages, eyes, ears. From the list of external manifestations of dysmorphogenesis of children of this group, including 55 dysplastic signs, 24 (43.6\%) were absent in children of the second group.

The unfavorable factors of the formation of a syndrome of bronchial obstruction include the age of a mother older than 30 years and father's age older than 36 years, children born of the $3^{\text {rd }}$ or more pregnancies and childbirth, and burdened with an antenatal period of development of the fetus (anemia in pregnant women, manifestations of pregnancy gestosis, threat of premature abortion) and bad habits (including smoking) of mothers during this pregnancy.

Connective tissue dysplasia causes prolongation of cough symptoms and physical changes (in the form of box shades of percussion sound, hard breathing, dry and damp mid-rash wheezing), which lead to the need of longer usage of mucolytic drugs.

Keywords: acute bronchitis, connective tissue dysplasia, children.

Research relation to the programs, plans, and department themes. The work is carried out within the framework of the general research work of the departments of pediatric profile of KhNMU "Medical and biological adaptation of children with somatic pathology in modern conditions", the State Registration Number is $0111 \mathrm{U} 001400$.

Introduction. Respiratory diseases remain the most common pathology in the pediatric population in recent years. While there is an evidence for variations in prevalence rates of childhood wheeze and asthma between countries, longitudinal, individual-level data are needed to understand these differences [1].

We analyzed datasets from 10 MeDALL (Mechanisms of the Development of ALLergy) cohorts in eight countries, representing 26663 children, to calculate prevalence rates of wheeze and asthma by child age and wheeze with asthma at age of 4 years. [2]. At the age of 4 years, wheeze varied from $9.82 \%(95 \% \mathrm{Cl}$ $7.95-11.96 \%)$ in Greece to $55.37 \%(95 \%$ Cl $52.21-$ $58.51 \%$ ) in Spain [3].

Taking into account the high prevalence of diseases of the lower airways, the study of the peculiari- 
ties of the course and the search for new ways to treat and rehabilitate patients in this category is very relevant.

In recent years, convincing data have been obtained on the peculiarities of the course of a number of diseases on the background of connective tissue dysplasia (CTD) [4]. CTD is one of the most important and little-studied problems [5]. Data on the prevalence of CTD are highly controversial: from $26 \%$ to $86 \%$ in the population, which is due to different diagnostic approaches of clinicians.

Despite the growing interest of domestic and foreign scientists to this problem, there is currently no single classification of the CTD, there are no common approaches to the treatment and rehabilitation of such patients, the search for pathogenetic mechanisms of the effect of DST on the course and the outcome of associated diseases continues [6, 14].

For the last 20 years, many works have been published viewing bronchial dysfunction as a manifestation of the violation of the cartilage and connective tissue of the trachea and bronchial tubes in dysplasia of the connective tissue, which leads to tracheobronchial dyskinesia $[4,5,7,8,12]$, and to the disturbance of drainage and ventilation function of the bronchial tubes. Changes in connective tissue associated with a violation of the synthesis and the function of derivatives of collagen and elastic proteins, Beighton $P$. (1983) proposed to be called connective tissue dysplasia. It is a polygenic multifactorial state, which is manifested by external and internal phenotypic features, as well as clinically significant dysplasticdependent disorders of the organs and systems functions. The basis of the development of CTD is the mutation of the genes responsible for the synthesis or disintegration of the components of the extracellular matrix of the connective tissue [9]. This is not a disease; it is a condition, based on the corresponding reaction of the organism to the influence of adverse factors.

The high population density of CTD and the unique role of connective tissue in the implementation of various functions of organs and systems of the body, certainly, significantly affects the clinical course of bronchopulmonary disease $[6,8,9,10]$.

The correlation between the presence of tracheobronchial dyskinesia and other phenotypic signs of "weakness" of the connective tissue, which may indicate the generalized nature of dysplasia, is noted. The clinical significance of tracheobronchial dyskinesia is that it acts as one of the causes of bronchial obstruction and chronic coughing $[11,13,16]$. Due to the mechanisms of hyperventilation and local inflammation, bronchial tubes obstruction leads to the development of emphysema of the lungs, chronic bronchitis, pulmonary heart $[6,9,10,11]$. Increased elasticity and reduced elasticity of the pulmonary tissue contribute to the development of polycystic lungs, bronchiectases, bullous emphysema [6, 16]. Patients with a CTD syndrome are more likely to exhibit spontaneous pneumothorax $[6,15]$, and they also have a recurring course of bronchopulmonary diseases $[9,10]$.

The purpose of the article was to study the peculiarities of the clinical course of acute bronchitis in children on the background of undifferentiated connective tissue dysplasia (UCTD).

Materials and methods. The study included 72 children aged from 2 to 5 years undergoing the hospital care because of acute simple or acute obstructive bronchitis, for the purpose of treatment or refinement of the diagnosis.

The study followed the basic bioethical provisions of the Council of Europe Convention on Human Rights and Biomedicine (04.04.1997), the World Health Association's Helsinki Declaration on Ethical Principles for Human Research (1964-2008), and the Order Ministry of Health of Ukraine No. 690 of September 23, 2009. Parents of each study patient signed an informed consent to participate in the study and all measures to ensure anonymity of patients were taken.

The assessment of the patient's condition included a complete physical examination and a laboratory-instrumental study for verifying the diagnosis, in accordance with the orders of the Ministry of Health of Ukraine No. 18 dated 13.01.2005. "On Approval of the Protocols for the Provision of Medical Aid to Children in the field of Pediatric Pulmonology" and relevant recommendations.

In the course of the study, the following methods were used: clinical-anamnestic, general-clinical, physical examination, radiography of the chest.

Functional research methods included: standard electrocardiography (ECG) at rest, ultrasound of the abdominal cavity, kidneys, heart. The level of total IgE in serum was determined using the enzyme test system «Granum» (Ukraine).

To assess the state of connective tissue metabolism, a daily excretion of the metabolite of connective tissue - oxyproline in a daily urine sample was determined, using the method of M. I. Kartashova and sponsors (2008p.). Metabolism of glycosaminoglycans (GAG) was investigated by the level of uronic acids in daily urine by reaction with carbazole by the method of D. V. Kosygin (1988). Determination of the level of GAG was performed by the method of F. S. Leontyeva and sponsors. (2008).

During the determining the availability of CTD, the levels of stigmatization (a conditional indicator that includes the total number of CTD points with a low (up to 12 points), average (13-24) and high (more than 
24 points) levels (using the table "Values of indicators in the assessment" degree of severity of connective tissue dysplasia ", T. I. Kadurina, L. N. Abakumova, 2008) were taken into account.

For static processing of the results of the study, STATISTICA 7.0 software package of StatSoft Inc. was used for a personal computer on the Windows system. The statistical null hypothesis on the correspondence of the data to a normal law was verified using the Shapiro-Wilk tests which is used for the initially unknown mean value and the mean square deviation. the obtained results (the central values of the sample) are presented in the form of Median Me, the lower and upper quartile Lq, Uq for each sign - Me (Lq, Uq), because not all of the data received had normal distribution. The analysis of qualitative data included the calculation of absolute and relative frequencies for each characteristic. By the results of the calculation, a comparison of the control and the main groups was performed by checking the null hypothesis about the equality of relative frequencies using the "Probabilistic Calculator" of the application package STATISTICA using a two-way criterion of statistical significance, when it is unknown which of the groups prevails over the frequency. As a threshold level of statistical significance, the value of 0.05 was taken. Also, Mann-Whitney's non-parametric criterion for independent groups and the Wilcoxon criterion for dependent groups were used.

Results. In the course of the study 72 inpatient care patients were examined. The average age of patients was $4.5(3.0 ; 5.0)$ years. Patients were divided into 2 groups. The $1^{\text {st }}$ (main) group included 41 children with acute obstructive bronchitis, which occurred on the background of UCTD: 22 children (group 1A) and 19 children without signs of UCTD (1B group). The second (comparative) group consisted of 31 children with simple acute bronchitis (without broncho-obstructive syndrome), which occurred on the background of UCTD: 16 children (2A group) and 15 children without signs of UCTD (2B group). In the analysis of the metabolic rate in the serum of children, a decrease in the general GAG in the children of the main group was found (Table 1). The most significant decrease was recorded at the expense of 2 and 3 fractions, which included chondroitin -4-sulfate (the $2^{\text {nd }}$ fraction) and heparan sulfate (the $3^{\text {rd }}$ fraction) present in the lung tissue.
The deficiency of chondroitin-4-sulfate (which is a component of the vessel wall) and heparan sulfate (the main component of the vessel glycoprotein frame) reflects functional and structural endothelium abnormalities during bronchopulmonary diseases. Most of the function of the endothelium is realized due to its interaction with the intercellular matrix of the connective tissue, GAG are the part of the glycocalix of the endothelium and are presented in the basal membrane of the vessel wall. During acute respiratory diseases on the background of ventilation disorders and alveolar hypoxia, the disorganization of the matrix of the connective tissue is pathognomonic in maintaining the pathological process in the respiratory tract. In assessing the levels of biochemical markers for connective tissue metabolism (levels of chondroitin sulfate in the blood and uronic acid in urine), a significant increase in the level of chondroitin sulfate and in the concentration of GAG metabolites in urine by the level of uronic acids was noted. The lowest level of disorganization of connective tissue was observed in children of $2 \mathrm{~A}$ groups with the predominantly decreased level of heparan sulfates ( $3^{\text {rd }}$ fraction).

It was established that the phenotypic portrait of children of the main group was characterized by dysplastic skeleton, skin and its appendages, eyes and ears disorders. From the list of external manifestations of the dysmorphogenesis of this group of children, which includes 55 dysplastic signs, 24 (43.6\%) were absent in the children of the comparison group. The obtained data testify that among children at the age of 1-5 years there was a diversity of dysplastic manifestations, indicating the lack of maturity of the connective tissue during this period of life. The multitude of

Table 1 - Characteristics of the parameters of the connective tissue metabolism in serum of blood and urine among children on the background of acute bronchitis (Me (Lq; Uq)

\begin{tabular}{l|c|c|c|c}
\hline \multirow{2}{*}{ Indicator } & \multicolumn{3}{|c|}{$\begin{array}{c}\text { Children with acute } \\
\text { obstructive bronchitis }\end{array}$} & $\begin{array}{c}\text { Children with acute bronchitis } \\
\text { without broncho-obstructive } \\
\text { disorders }\end{array}$ \\
\cline { 2 - 5 } & 1A group & 1B group & 2A group & 2B group \\
\hline \multicolumn{4}{|c}{ Blood serum } \\
\hline $\begin{array}{l}\text { General level } \\
\text { of GAG, unit }\end{array}$ & 8,6 & 10,3 & 11,45 & 10,1 \\
\hline $1^{\text {st }}$ fraction, & $6,1 ; 9,2]$ & {$[9,5 ; 13,4]$} & {$[9,3 ; 13,6]$} & {$[8,9 ; 12,6]$} \\
\hline unit & {$[5,9 ; 6,9]$} & 6,41 & 6,45 & 6,3 \\
\hline $2^{\text {nd }}$ fraction, & 1,65 & 2,85 & {$[6,1 ; 7,2]$} & {$[6,1 ; 7,1]$} \\
unit & {$[1,5 ; 3,1]$} & {$[2,2 ; 3,3]$} & {$[2,4 ; 3,3]$} & {$[2,6 ; 3,85]$} \\
\hline $3^{\text {rd } \text { fraction, }}$ & 1,3 & 2,5 & 1,65 & 3,4 \\
unit & {$[1,1 ; 1,9]$} & {$[2,1 ; 3,05]$} & {$[1,1 ; 2,35]$} & {$[2,2 ; 3,9]$} \\
\hline Chondroitin & 0,118 & 0,112 & 0,104 & 0,120 \\
sulfates, g/l & {$[0,097 ; 0,158]$} & {$[0,092 ; 0,147]$} & {$[0,085 ; 0,118]$} & {$[0,118 ; 0,158]$} \\
\hline \multicolumn{5}{|c}{ Daily urine } \\
\hline Uronic acids, & 4,65 & 3,8 & 4,3 & 3,4 \\
mg/ml & {$[3,3 ; 6,4]$} & {$[3,3 ; 4,2]$} & {$[3,15 ; 6,75]$} & {$[3,4 ; 4,1]$} \\
\hline
\end{tabular}


lesions is due to the fact that the teratogenic period for many organs and systems is approximately the same. In this situation, the identification of factors that disturb the normal morphogenesis of the connective tissue becomes of particular importance.

It was established that patients in the main group more often were born from 3 or more births, in the first place from mothers at the age of 30 years and older (41.58 and $26.92 \%$, respectively, $p<0.02$ ) than the children of the comparison group. Parents over the age of 36 years were 3 times more in the main group (10.89 and $3.08 \%$, respectively, $p>0.05$ ). The parents' age during the birth of children is of special importance, since it increases the risk of mutagenic influences on the maternal, parental and infant body increases.

The antenatal period of development of the main group children proceeded on the background of abnormal pregnancy in $83.17 \%$ of mothers. They had anemia (46.53 and 29.23\%, respectively, $p<0.01$ ), manifestations of pregnancy gestosis (41.58 and $26.92 \%$, respectively, $p<0.02)$, the threat of premature abortion (46.53 and $29.23 \%$, respectively, $\mathrm{p}<0.01$ ), and bad habits (including smoking) more often than in the comparison group. Differences in the social status of families of patients in the surveillance groups were not registered.

In the analysis of clinical manifestations of simple bronchitis, we found that the severity of the disease determined by the degree of severity and duration of symptoms, was associated with the number of signs of UCTD. Thus, febrile fever among children of the main group was registered 2.6 times more often than in the comparison group (in 40.35 and $15.07 \%$, respectively, $p<0.001$ ), with the timing of normalization of body temperature at $38.60 \%$ patients with UCTD delayed more than 5 days.

Characteristics of cough among children of both groups did not have significant differences except the long terms of preservation of this symptom in patients with UCTD.

Auscultatory changes were characterized by dry and damp mid-rash wheezing on the background of hard breath for 1.5-2 weeks.

Discussion. For many years authors focused their studies on early identifying children with recurrent wheezing at risk to develop asthma at school age [17]. In addition, several population-based birth cohort studies documented that $30 \%$ of children suffer from wheezing during respiratory infections before their third birthday [18].
Connective tissue dysplasia has a modifying effect on the course of acute bronchitis, resulting in greater severity and prolongation of the leading symptoms and syndromes. The study revealed the negative impacts of environmental factors and pathological course of pregnancy on the development of obstructive bronchitis and undifferentiated connective tissue dysplasia [19].

Literary evidence suggested that the search for statistically significant markers and risk criteria for the formation of bronchial obstructive syndrome in children should be still ongoing.

Multiple phenotypic traits of UCTD that cause morphofunctional changes in the bronchopulmonary system may serve as markers of the earliest age, different in severity and duration of manifestations of bronchial obstruction syndrome in children, requiring appropriate correction of therapeutic measures.

\section{Conclusion}

1. Among patients with acute bronchitis with the complication syndrome of wheezing, a phenotypic portrait was characterized by dysplastic disorder of the skeleton, skin and its appendages, eyes, ears. From the list of external manifestations of dysmorphogenesis in children of this group, which included 55 dysplastic signs, 24 (43.6\%) were absent in children with acute bronchitis without wheezing syndrome.

2. The unfavorable factors of the formation of the syndrome of bronchial obstruction include the age of a mother older than 30 years and father's age older than 36 years, children born from the $3^{\text {rd }}$ or more pregnancies and childbirth, and burdened with an antenatal period of development of the fetus (anemia in pregnant women, manifestations of pregnancy gestosis, threat premature abortion in the mother) and bad habits (including smoking) of mothers during this pregnancy.

3. UCTD causes prolongation of cough symptoms and physical changes (in the form of box shades of percussion sound, hard breathing, dry and damp midrash wheezing), which leads to the need for longer use of mucolytic drugs.

4. Among patients with acute bronchitis with the complication syndrome of wheezing with phenotypic signs of UCTD changings like a decrease in the general level of GAG, 2 and 3 GAG fractions, as well as an increase in the concentration of chondroitin sulfates in the blood serum and uronic acid levels in the urine were observed.

The prospect of further research will be the determination of certain genetic polymorphisms to identify the risks of developing bronchial obstruction syndrome in children with acute bronchitis.

\section{References}

1. Ducharme FM, Tse SM, Chauhan B. (2014). Diagnosis, management, and prognosis of preschool wheeze. Lancet. 2014 May 3; 383(9928): 1593-604. doi: 10.1016/S0140-6736(14)60615-2 
2. Stern DA, Morgan WJ, Halonen M, Wright AL, Martinez FD. Wheezing and bronchial hyper-responsiveness in early childhood as predictors of newly diagnosed asthma in early adulthood: a longitudinal birth-cohort study. Lancet. 2008; 372: 1058-64. PMID: 18805334. PMCID: PMC2831297. DOI: 10.1016/S0140-6736(08)61447-6

3. Uphoff EP, Bird PK, Antó JM, Basterrechea M, von Berg A, Bergström A, et al. Variations in the prevalence of childhood asthma and wheeze in MeDALL cohorts in Europe. ERJ Open Res. 2017; 3: 00150-2016. PMID: 28845428. PMCID: PMC5566268. Doi: 10.1183/23120541.00150-2016

4. Martinez FD, Wright AL, Taussig LM, Holberg CJ, Halonen M, Morgan WJ. Asthma and wheezing in the first six years of life. N Engl J Med. 1995; 332: 133-8. PMid:7800004. doi: 10.1056/NEJM199501193320301

5. Lasso-Pirot A, Delgado-Villalta S, Spanier AJ. Early childhood wheezers: identifying asthma in later life. J Asthma Allergy. 2015; 8: 63-73. PMID: 26203265. PMCID: PMC4508083. doi: 10.2147/JAA.S70066

6. Fedorov IA, Rybakova OG, Stepanov OG. Diagnostika bronkhialnoi astmy u detei, perenesshikh epizody ostrogo obstruktivnogo bronkhita $v$ doshkolnom vozraste /Diagnosis of bronchial asthma in children who had acute obstructive bronchitis at preschool age.]. Human Sport Medicine. 2017; 17(1): 28-35. doi: 10.14529/hsm170103

7. Luo G, Nkoy FL, Stone BL, Schmick D, Johnson MD. A systematic review of predicitve models for asthma development in children. BMC. Med Inform Decis Mak. 2015; 15: 99. PMID: 26615519. PMCID: PMC4662818. doi: 10.1186/ s12911-015-0224-9

8. Halper J, Kjaer M. Basic components of connective tissues and extracellular matrix: elastin, fibrillin, fibulins, fibrinogen, fibronectin, laminin, tenascins and thrombospondins. Adv Exp Med Biol. 2014; 802: 31-47. PMID: 24443019. doi: 10.1007/978-94-007-7893-1_3

9. Lapshin VF. Retsidiviruyushchii bronkhit u detei: diskussionnye voprosy diagnostiki i lecheniya. Recurrent bronchitis in children: controversial issues of diagnosis and treatment]. Pediatriya. 2017; 2(41): 10-1. [Russian]

10. Lee $\mathrm{P}, \mathrm{Khoo} \mathrm{KL}$. A review of current bronchoscopic interventions for obstructive airway diseases. Ther Adv Respir Dis. 2012; 6: 297-307. PMID: 22878625. doi: 10.1177/1753465812455448

11. Nesterenko Z.V. Retsidiviruyushchii bronkhit kak klinicheskii variant funktsionalnykh izmenenii respiratornoi sistemy u detei Recurrent bronchitis as a clinical variant of the functional changes in the respiratory system in children]. Pediatr. 2017; 8(5): 44-8. doi: 10.17816/PED8544-48

12. Mattiello R, Mallol J, Fischer GB. Pulmonary function in children and adolescents with postinfectious bronchiolitis obliteransiu. J Bras Pneumol. 2012; 4: 453-9.

13. Zhelenina LA, Galustyan AN, Platonova NB, Kuropatenko MV. Vklad perinatalnykh faktorov riska v formirovanie fenotipov bronkhialnoi astmy $v$ detskom vozraste [Contribution of prenatal factors and in formation of asthma phenotypes in children]. Pediatr. 2016; 7(2): 47-56. [Russian] doi: 10.17816/PED7247-56

14. Arsentev VH, Baranov VS, Shabalov NP. Nasledstvennye zabolevanyia soedynytelnoi tkany kak konstytutsyonalnaia prychyna polyorhannykh narushenyi u detei. Monohrafyia. SPb; 2013. 44 s. [Russian]

15. Strelkov NS, Kyldyiarova RR, Sharaev PN, Yshmamedov YL. Soedynytelnaia tkan u detei pry patolohyy. Monohrafyia. Pod red RR Kyldyiarovoi. Yzhevsk; 2011. 210 s. [Russian]

16. Yvanova YY, Hnusaev SF, Koval NYu, Herasymov NA, Soldatova YA. Metabolycheskye aspekti nedyfferentsyrovannoi dysplazyy soedynytelnoi tkany u detei. Rossyiskyi vestnyk perynatolohyy y pedyatryy. 2012; 57(4-1): 103-11. [Russian]

17. Laura Tenero, Michele Piazza, Giorgio Piacentini. Recurrent wheezing in children. Trans/ Pediatr. 2016 Jan; 5(1): 31-6.

18. El-Gamal YM, El-Sayed SS. Wheezing in infancy. World Allergy Organ J. 2011 May; 4(5): 85-90. PMID: 23282443. PMCID: PMC3651148. DOI: 10.1097/WOX.0b013e318216b41f

19. Semianchuk V, Haridzhuk L, Bobrykovych O. Indicators of phagocytic component and secretory iga in children with bronchial asthma secondary to undifferentiated connective tissue dysplasia. Georgian Med News. 2016 Nov; (Issue): 61-7.

Удк 616.233-002.1-0.18.2-071.1-053.2

ОСОБЛИВОСТІ ФЕНОТИПІЧНИХ ПРОЯВІВ, АНАМНЕЗУ

ТА МЕТАБОЛІЗМУ СПОЛУЧНОЇ ТКАНИНИ У ДІТЕЙ НА ТЛІ ГОСТРОГО БРОНХІТУ

Стрєлкова М. І., Сенаторова Г. С.

Резюме. Висока популяційна частота поширеності дисплазії сполучної тканини, унікальна роль сполучної тканини у здійсненні різних функцій органів та систем організму істотно впливає на клінічний перебіг бронхолегеневих захворювань у дітей. Відзначено взаємозв'язок між наявністю трахеобронхіальної дискінезії та іншими френотипічними ознаками «слабкості» сполучної тканини. Клінічне значення трахеобронхіальної дискінезії полягає в тому, що вона виступає однією з причин бронхіальної обструкції та хронічного кашлю. Через механізми гіпервентиляції та локального запалення обструкція бронхів може призводити до розвитку емфріземи легенів, хронічного бронхіту, легеневого серця.

До дослідження увійшло 72 пацієнта, що знаходилися на стаціонарному лікуванні (1 група - 41 дитина з гострим обструктивним бронхітом та 2 група - 31 дитина з гострим бронхітом простим). 
Для оцінки стану обміну сполучної тканини визначалися рівень глікозаміногліканів крові та добова екскреція метаболіту сполучної тканини - оксипроліну в добовій пробі сечі.

При встановленні наявності дисплазії сполучної тканини враховували рівні стигматизації (умовний показник, який включає сумарну кількість балів дисплазії сполучної тканини з виділенням низького, середнього та високого рівнів) із використанням таблиці «Значення показників в оцінці ступеня тяжкості дисплазії сполучної тканини».

Під час аналізу показників обміну сполучної тканини у сироватці крові дітей хворих на гострий бронхіт ускладнений бронхообструктивним синдромом з фенотипічними ознаками дисплазії сполучної тканини відзначаються зміни у вигляді зниження загального рівня глікозаміногліканів крові, 2 та 3 фракції глікозаміногліканів крові, а також підвищення концентрації хондроїтинсульфатів у сироватці крові та рівня уронових кислот у сечі

Фенотипічний портрет дітей першої групи характеризувався диспластичними порушеннями скелету, шкіри та її придатків, очей, вух. 3 переліку зовнішніх проявів дісморфогенезу дітей цієї групи, що включає 55 диспластичних ознак, 24 (43,6\%) були відсутні у дітей другої групи.

Ключові слова: гострий бронхіт, дисплазія сполучної тканини, діти.

УДК 616.233-002.1-0.18.2-071.1-053.2

ОСОБЕННОСТИ ФЕНОТИПИЧЕСКИХ ПРОЯВЛЕНИЙ, АНАМНЕЗА

И МЕТАБОЛИЗМА СОЕДИНИТЕЛЬНОЙ ТКАНИ У ДЕТЕЙ

НА ФОНЕ ОСТРОГО БРОНХИТА

Стрелкова М. И., Сенаторова Г. С.

Резюме. Высокая популяционная частота распространенности дисплазии соединительной ткани, уникальная роль соединительной ткани в осуществлении различных фрунций органов и систем организма существенно влияет на клиническое течение бронхолегочных заболеваний у детей. Отмечена взаимосвязь между наличием трахеобронхиальной дискинезии и другими фенотипическими признаками «слабости» соединительной ткани. Клиническое значение трахеобронхиальной дискинезии заключается в том, что она выступает одной из причин бронхиальной обструкции и хронического кашля. Через механизмы гипервентиляции и локального воспаления обструкция бронхов может приводить к развитию эмфиземы легких, хронического бронхита, легочного сердца.

В исследование вошло 72 пациента, находившихся на стационарном лечении (1 группа - 41 ребенок с острым обструктивным бронхитом и 2 группа - 31 ребенок с острым бронхитом простым).

Для оценки состояния обмена соединительной ткани определялись уровень гликозаминогликанов крови и суточная экскреция метаболита соединительной ткани - оксипролина в суточной пробе мочи.

При установлении наличия дисплазии соединительной ткани учитывали уровни стигматизации (условный показатель, включающий суммарное количество баллов дисплазии соединительной ткани с выделением низкого, среднего и высокого уровней) с использованием таблицы «Значение показателей в оценке степени тяжести дисплазии соединительной ткани».

При анализе показателей обмена соединительной ткани в сыворотке крови у детей с острым обструктивным бронхитом с фенотипическими признаками дисплазии соединительной ткани отмечаются изменения в виде снижения общего уровня гликозаминогликанов крови, 2 и 3 фракции гликозаминогликанов крови, а также повышение концентрации хондроитинсульфата в сыворотке крови и уровня уроновых кислот в моче.

Фенотипический портрет детей первой группы характеризовался диспластическими нарушениями скелета, кожи и ее придатков, глаз, ушей. Из перечня внешних проявлений дисморфогенеза детей этой группы, включающей 55 диспластических признаков, 24 (43,6\%) отсутствовали у детей второй группы.

Ключевые слова: острый бронхит, дисплазия соединительной ткани, дети.

The authors of this study confirm that the research and publication of the results were not associated with any conflicts regarding commercial or financial relations, relations with organizations and/or individuals who may have been related to the study, and interrelations of coauthors of the article. 